\title{
Detection of genetically modified organisms in soy feed and food in Romania
}

\author{
FLORICA BARBUCEANU ${ }^{1,2}$, IULIA ZYBACZYNSKI ${ }^{2}$, DIANA IONELA \\ DUMITRESCU ${ }^{2}$, GABRIEL PREDOI ${ }^{1}$, STELIAN BARAITAREANU ${ }^{1}$
}

\footnotetext{
${ }^{1}$ University of Agronomical Sciences and Veterinary Medicine of Bucharest, Splaiul Independentei 105, District 5, 050097, Bucharest, Romania

${ }^{2}$ Institute for Diagnosis and Animal Health, 63 Dr Staicovici Nicolae Str, District 5, 050557, Bucharest, Romania
}

\begin{abstract}
The paper describes the diagnostic methods used in Romania to detect the genetically modified organisms in soy feed and food and the results recorded between 2013 and 2019. The retrospective analyses of surveillance and diagnostic methods (qualitative and quantitative PCR techniques) developed for the genetically modified organisms detection in soy feed and food and of the transgenic Roundup Ready soybean line event 40-3-2 in Romania covered a total of 687 tests between 2013 and 2019 and revealed 32/131 GM events in 2013, 25/142 GM events in 2014, 24/117 GM events in 2015, 16/115 GM events in 2016, 6/97 GM events in 2017, 8/53 GM events in 2018, and 2/32 GM events in 2019.
\end{abstract}

Keywords GMO, genetically modified organisms, Roundup Ready, Glycine max, PCR.

To cite this article: BARBUCEANU F, ZYBACZYNSKI I, DUMITRESCU DI, PREDOI G, BARAITAREANU S. Detection of genetically modified organisms in soy feed and food in Romania. Rom Biotechnol Lett. 2021; 26(1): 2223-2229. DOI: $10.25083 / \mathrm{rbl} / 26.1 / 2223.2229$

*Corresponding author: FLORICA BARBUCEANU, Doctor of Veterinary Medicine, PhD, Associate Professor, Department of Preclinical Sciences, Faculty of Veterinary Medicine, University of Agronomical Sciences and Veterinary Medicine of Bucharest, Splaiul Independentei 105, sector 5, 050097, Bucharest, Romania, Tel/Fax: +4021- 318.04.69/ +4021- 318.04.98 Institute for Diagnosis and Animal Health, 63 Dr Staicovici Nicolae Str, sector 5, 050557, Bucharest, Romania, Tel/Fax: +40374322000/ +4021-4113394

E-mail: florica.barbuceanu@idah.ro 


\section{Introduction}

World Health Organization defined GMO as "[...] organisms (i.e. plants, animals or microorganisms) in which the genetic material (DNA) has been altered in a way that does not occur naturally by mating and/or natural recombination." (OIE, 2014 [1]). The possible adverse effects of the genetic modified crops on human health and environmental safety are mostly focused on doubts but they are scientifically probable, and presented in good faith (ZHANG \& al, 2016 [2]). Despite of the possibility of the unintended effects, the benefits of the genetic modified crops are not negligible mainly for countries where the food security challenges are linked with the crisis of water paucity and reduced rainfall [DADGARNEJAD \& al, 2017 [3]).

The European Union made the legislation to ensure the safety of feed and food before the placing on the market of any GMO, in which the labelling of food products sold in EU market made with GMO is mandatory (EU, 2001[4]; EU, 2003 [5]; EU, 2003 [6]; EU, 2009 [7]; EU, 2011 [8]; EU, 2015 [9]).

Soy is an important source of food, reach in protein and oil, whose production has grown continuously around the world (FRIEDMAN \& BRANDON, 2001 [10]; KORTH, 2008 [11]; JAMES, 2011 [12]).

40-3-2 is a variety of genetically modified soy, also known as Roundup Ready (RR), grown in many countries (CROPLIFE, 2017 [13]) due to the ability to not be destroyed by action of the herbicide glyphosate (PADGETTE \& al, 1995 [14]). The genetically modified soybean line Roundup Ready GTS 40-3-2 was developed by Monsanto Company and was based on recombinant DNA technology, which targeted the gene synthesizing 5-enolpyruvylshikimate3-phosphate synthase (EPSPS), which was isolated from the CP4 strain of Agrobacterium tumefaciens. Several soy products with GMO events have been recorded in the last years (Table 1), and the detection and identification of genetically modified soy in food and feed become an important activity of national and international authorities.

Common technique used for the detection and identification of genetically modified soy in food and feed analyses is polymerase chain reaction (LAU \& al, 2004 [15]; SIERADZKI \& al, 2008 [16]). The Romanian Reference Laboratory for Genetically Modified Organisms is hosted by the Molecular Biology Service of the Institute of Diagnosis and Animal Health.

The aim of study was the retrospective analyses of surveillance and diagnostic methods (qualitative and quantitative PCR techniques) developed for the genetically modified organisms' detection in soy feed and food and of the transgenic Roundup Ready soybean line event 40-3-2 in Romania.

Table 1. GMO soy (Glycine max) products with or without the 35S promoter and / or the NOS terminator

\begin{tabular}{|c|c|c|c|c|c|}
\hline \multirow{2}{*}{ Product code } & \multirow{2}{*}{ GMO event } & \multicolumn{2}{|c|}{ P35S } & \multicolumn{2}{|c|}{ T-nos } \\
\hline & & $\mathrm{T}$ & $\mathrm{V}$ & $\mathrm{T}$ & $\mathrm{V}$ \\
\hline 260-05 (=G94-1, G94-19, G168) & DD-026005-3 & + & & + & \\
\hline 305423 & DP-305423-1 & - & $*$ & - & $*$ \\
\hline 356043 & DP-356043-5 & + & + & - & $*$ \\
\hline A2704-12 & ACS-GM005-3 & + & + & - & - \\
\hline A2704-21, A5547-35 & ACS-GM004-2 & + & & - & \\
\hline A5547-127 (LibertyLink) & ACS-GM006-4 & + & + & - & - \\
\hline BPS-CV127-9 & BPS-CV127-9 & - & - & - & - \\
\hline DAS-44406-6 & DAS-44406-6 & - & - & - & - \\
\hline DAS-68416-4 & DAS-68416-4 & - & - & - & - \\
\hline DAS-81419-2 & DAS-81419-2 & - & - & - & - \\
\hline FG72 & MST-FG072-2 & - & - & + & + \\
\hline GTS 40-3-2 (Roundup Ready) & MON-04032-6 & + & + & + & + \\
\hline GU262 (LibertyLink) & ACS-GM003-1 & + & & - & \\
\hline MON87701 & MON-87701-2 & - & - & - & - \\
\hline MON87705 & MON-87705-6 & - & - & - & - \\
\hline MON87708 & MON-87708-9 & - & - & - & - \\
\hline MON87712 & MON-87712-4 & + & & - & \\
\hline MON87751 & MON-87751-7 & - & & - & \\
\hline MON87769 & MON-87769-7 & - & - & - & - \\
\hline MON89788 & MON-89788-1 & - & $*$ & - & $*$ \\
\hline SYHTOH2 & SYN-000H2-5 & + & + & + & + \\
\hline W62, W98 (Liberty Link) & ACS-GM001-8 & + & & + & \\
\hline
\end{tabular}

"-" the event does not contain the screening element, "+" the event contains the screening element, "T" present theoretically (based on information from the EUginius database), "V" verified using reference materials or other controls, "* " Unexpected results

\section{Experimental part}

\section{Materials and methods}

The methodology of this study followed all European Union, European Committee for Standardization and Romanian competent authorities' recommendations in the field of GMOs testing (EU, 2001 [4]; EU, 2003 [5]; EU, 2003 [6]; EU, 2009 [7]; EU, 2011 [8]; EU, 2015 [9]; EN/TS, 2006 [17]; ISO, 2006 [18]).

\section{Food and feed samples}

DNA isolation and purification were carried out between 2013 and 2019 from various raw or processed food and feed with soy (Table 2) from Romanian market in accord with general requirements and definitions and sampling strategies of analysis for the detection of genetically modified organisms and derived products (EN/TS, 2006 [17]; ISO, 2006 [18]). 
Table 2. Soy food and feed samples analysed between 2013 and 2018

\begin{tabular}{|l|c|c|c|c|c|c|c|}
\hline MATRIX & $\mathbf{2 0 1 3}$ & $\mathbf{2 0 1 4}$ & $\mathbf{2 0 1 5}$ & $\mathbf{2 0 1 6}$ & $\mathbf{2 0 1 7}$ & $\mathbf{2 0 1 8}$ & $\mathbf{2 0 1 9}$ \\
\hline Soya beans & 18 & 34 & 39 & 10 & 19 & 8 & 2 \\
\hline Feed with soy & 11 & 2 & 7 & 16 & 0 & 5 & 0 \\
\hline Food with soya & 102 & 106 & 71 & 89 & 78 & 40 & 30 \\
\hline Total & $\mathbf{1 3 1}$ & $\mathbf{1 4 2}$ & $\mathbf{1 1 7}$ & $\mathbf{1 1 5}$ & $\mathbf{9 7}$ & $\mathbf{5 3}$ & $\mathbf{3 2}$ \\
\hline
\end{tabular}

\section{DNA extraction, quantification and purity}

For each analytical sample, DNA extraction was performed in duplicate in accord with standardised methods of analysis for the detection of genetically modified organisms and derived products (ISO, 2005 [19]; ISO/TS, 2005 [20]).

Samples were grinded with Maxi Grinder Solo (Genomic Industry, France) and Grindomix GM 200 (Retsch, Germany) in particles with size below 500 microns and the DNA extraction were performed with NucleoSpin Food kit (Macherey-Nagel, Germany) or GENESpin kit (Eurofins GeneScan, Germany) by using $200 \mathrm{mg}$ sample/test. The extraction was carried out according to the manufacturer instructions.

Briefly, the steps of the DNA extraction with NucleoSpin Food kit (Macherey-Nagel, Germany) were (1) Incubation with lysis buffer, (2) Digestion of endogenous nucleases and other impurities in the presence of Proteinase K; (3) Binding DNA to the silica membrane of NucleoSpin Food tubes; (4) Washing DNA, purifying salts, proteins and other cellular impurities; and (5) Recovering of the purified DNA with elution buffer. Purified DNA is free of contaminants and enzyme inhibitors, being usable in all types of genetically modified DNA detection and quantification reactions. DNA concentration and purity were determined spectrophotometrically. After completing the extraction steps, 0.1-10 $\mu \mathrm{g}$ nucleic acids / $200 \mathrm{mg}$ sample were obtained, the amount depending on the type of matrix analysed.

Briefly, the steps of the DNA extraction with GeneSpin kit (Eurofins GeneScan, Germany) were (1) Homogenization of the sample and lysis of cells: $550 \mu \mathrm{CF}$ lysis buffer, preheated to $65^{\circ} \mathrm{C}$, is homogenised with $200 \mathrm{mg}$ of sample in $2 \mathrm{ml}$ centrifuge tubes; (2) Adjusting the DNA binding conditions with $200 \mu$ l ethanol; (3) DNA binding: The sample is loaded into the filters combined with the collection tubes; (4) Washing and drying with CQW washing buffer and working solution of C5 (C5 buffer $+80 \mathrm{ml}$ ethanol); (5) DNA elution with CE elution buffer, preheated to $70^{\circ} \mathrm{C}$ : two elution steps are performed using $2 \times 100 \mu 1$ of elution buffer, the filters were incubated for 5 minutes at $18-25^{\circ} \mathrm{C}$ and centrifuged $1 \mathrm{~min}$, at $\sim 13000 \mathrm{rpm}$.

\section{Qualitative PCR detection methods used to identify GMOs}

The test procedure comprises identifying the presence of plant-specific DNA and identifying genetically modified material by PCR methods for detecting genetic elements that can be found in most GMOs (35S promoter and / or NOS terminator). The identification of these genetic elements has the disadvantage that they can be present naturally in the host organism, due to the presence of viruses (Cauliflower Mosaic Virus) and/or bacteria (Agrobacterium tumefaciens) that contain these elements.

Qualitative nucleic acid-based methods used in this study were in accord with the standardised methods of analysis for the detection of genetically modified organisms and derived products [ISO, 2005 [20]; ISO, 2005 [21]).

Taxon-specific PCR system: identification of the soybean plant-specific sequence Glycine max L. (lectin)

DNA identification specific to the GTS 40-3-2 line was performed using either a dedicated kit "GMO Ident Roundup Ready Soy" (Eurofins GeneScan, Germany) with TaqDNA polymerase (AmpliTaqTM Gold DNA Polymerase) 5UI / $\mu 1$, or the in-house method with primers and probes.

Identification of GTS 40-3-2 line-specific DNA (qualitative detection methods) using the "GMO Ident Roundup Ready Soy" kit (Eurofins GeneScan, Germany) was made in accordance with the manufacturer's recommendations. The kit allows the identification by amplifying a specific $128 \mathrm{bp}$ sequence of the lectin (Le1) gene, naturally present in the genome of the soybean plant, indicating the presence of plant-specific DNA and the lacking of inhibitory compounds in the isolated DNA solution.

$20 \mu \mathrm{l}$ Master Mix $+5 \mu \mathrm{l}$ DNA (50-100 ng) / $\mathrm{H}_{2} \mathrm{O}$ were pipetted on ice / cooling block avoiding the generation of air bubbles following pipetting, centrifuged in the cold for a few seconds and placed on the thermocycler according to the operating parameters described in Table 3.

Table 3. The thermocycler operating parameters for the soybean specific DNA identification with GMO Ident Roundup Ready Soy Kit (Eurofins Genescan, Germany)

\begin{tabular}{|l|c|c|c|}
\hline Step & Temperature $\left({ }^{\mathbf{0}} \mathbf{C}\right)$ & Time & Number of cycles \\
\hline Initial Denaturation & 94 & $10 \mathrm{~min}$ & $1 \mathrm{x}$ \\
\hline Denaturation & 94 & $25 \mathrm{sec}$ & \multirow{2}{*}{$50 \mathrm{x}$} \\
\hline Annealing & 62 & $30 \mathrm{sec}$ & \\
\hline Extension & 72 & $45 \mathrm{sec}$ & $1 \mathrm{x}$ \\
\hline Final Extension & 72 & $3 \mathrm{~min}$ & - \\
\hline Hold & 4 & $\infty$ & \\
\hline
\end{tabular}


For the in-house method, reagents were mixed according to the protocol detailed in Table 4 with the soybean specific sequence forward primer GMO3:
5'-GCC CTC TAC TCC ACC CCC ATC C -3', and reverse primer GMO4: 5'-GCC CAT CTG CAA GCC TTT TTG TG -3 ,

Table 4. PCR reaction mixture for the soybean specific DNA identification with the in-house method

\begin{tabular}{|l|c|c|}
\hline Reagent & Final concentration of the mix & $\begin{array}{c}\text { Volume per } \\
\text { reaction }(\boldsymbol{\mu l})\end{array}$ \\
\hline Nuclease-free $\mathrm{H}_{2} \mathrm{O}$ & - & 28.75 \\
\hline Buffer $5 \mathrm{X}\left(\right.$ without $\left.\mathrm{MgCl}_{2}\right)$ & $1 \mathrm{x}$ & 10 \\
\hline $\mathrm{MgCl}_{2}(25 \mathrm{mM})$ & $1.5 \mathrm{mM}$ & 3 \\
\hline $\mathrm{dNTPs}(10 \mathrm{mM})$ & $0.4 \mathrm{mM}$ & 1 \\
\hline $\mathrm{GMO}_{3}(20 \mu \mathrm{M})$ & $0.4 \mu \mathrm{M}$ & 1 \\
\hline $\mathrm{GMO}_{4}(20 \mu \mathrm{M})$ & $0.4 \mu \mathrm{M}$ & 1 \\
\hline Taq DNA polymerase $(5 \mathrm{UI} / \mu \mathrm{l})$ & $0.625 \mathrm{U}$ & 0.25 \\
\hline TOTAL $(\mu \mathrm{l})$ & & 45 \\
\hline
\end{tabular}

$45 \mu 1$ Master mix GMO3/GMO4 + $5 \mu 1$ ADN (50-200 ng) / $\mathrm{H} 2 \mathrm{O}$ were pipetted on ice/ cooling block avoiding the generation of air bubbles following pipetting, centrifuged in the cold for a few seconds and placed on the thermocycler according to the operating parameters described in Table 5.

Table 5. The thermocycler operating parameters for the soybean specific DNA identification with the in-house method

\begin{tabular}{|l|c|c|c|}
\hline Step & Temperature $\left.\mathbf{~}^{\circ} \mathbf{C}\right)$ & Time & Number of cycles \\
\hline Initial Denaturation & 95 & $5 \mathrm{~min}$. & \\
\hline Denaturation & 95 & $30 \mathrm{sec}$. & \multirow{2}{*}{$40 \mathrm{x}$} \\
\hline Annealing & 63 & $30 \mathrm{sec}$. & \\
\hline Extension & 72 & $30 \mathrm{sec}$. & \\
\hline Final Extension & 72 & $3 \mathrm{~min}$ & \\
\hline Hold & 4 & $\infty$ & \\
\hline
\end{tabular}

PCR system specific to the genetic construct: identification of the sequence representing the junction region between the CaMV $35 S$ promoter and the CTP4 (Chloroplast Transit Peptide) sequence derived from Petunia hybrida

PCR primers for the sequence representing the junction region between the CaMV $35 \mathrm{~S}$ promoter and the CTP4 sequence are primer forward 35s-f2: 5'-TgA TgT GAT ATC TCC ACT gAC g-3'and primer reverse petu-r1: 5'-TgT ATC CCT TgA gCC ATg TTg T -3'. Reagents were mixed according to the protocol detailed in Table 6 .

Table 6. PCR reaction mixture for the identification of the sequence representing the junction region between the CaMV 35S promoter and the CTP4 (chloroplast transit peptide)

\begin{tabular}{|l|c|c|}
\hline Reagent & $\begin{array}{c}\text { Final concentration } \\
\text { of the mix }\end{array}$ & Volume per reaction $(\boldsymbol{\mu l})$ \\
\hline Nuclease-free $\mathrm{H} 2 \mathrm{O}$ & - & 13.375 \\
\hline Buffer $10($ without $\mathrm{MgCl} 2)$ & $1 \mathrm{x}$ & 2.5 \\
\hline $\mathrm{MgCl} 2(25 \mathrm{mM})$ & $1.5 \mathrm{mM}$ & 2 \\
\hline $\mathrm{dNTPs}(10 \mathrm{mM})$ & $0.4 \mathrm{mM}$ & 0.5 \\
\hline $35 \mathrm{~s}-\mathrm{f} 2(20 \mu \mathrm{M})$ & $0.4 \mu \mathrm{M}$ & 0.5 \\
\hline petu-r1 $(20 \mu \mathrm{M})$ & $0.4 \mu \mathrm{M}$ & 0.125 \\
\hline $\begin{array}{l}\text { Taq DNA polymerase } \\
(5 \mathrm{UI} / \mu \mathrm{l})\end{array}$ & $0.625 \mathrm{U}$ & 20 \\
\hline TOTAL $(\mu \mathrm{l})$ & & \\
\hline
\end{tabular}

$20 \mu \mathrm{l}$ Master Mix 35s-f2/petu-r1 + $5 \mu \mathrm{l}$ ADN (50-200 ng) / H2O, were pipetted on ice / cooling block avoiding the generation of air bubbles following pipetting, centrifuged in the cold for a few seconds and placed on the thermocycler according to the operating parameters described in Table 7. 
Table 7. The thermocycler operating parameters for the identification of the sequence representing the junction region between the CaMV 35S promoter and the CTP4 (chloroplast transit peptide)

\begin{tabular}{|l|c|c|c|}
\hline Step & Temperature $\left({ }^{\circ} \mathbf{C}\right)$ & Time & Number of cycles \\
\hline Initial Denaturation & 95 & $5 \mathrm{~min}$. & \\
\hline Denaturation & 95 & $30 \mathrm{sec}$. & \multirow{2}{*}{$40 \mathrm{x}$} \\
\hline Annealing & 60 & $30 \mathrm{sec}$. & \\
\hline Extension & 72 & $25 \mathrm{sec}$. & \\
\hline Final Extension & 72 & $3 \mathrm{~min}$ & \\
\hline Hold & 4 & $\infty$ & \\
\hline
\end{tabular}

\section{Agarose gel electrophoresis of PCR products}

The results were assessed by agarose gel electrophoresis $(2.5 \%$, w/v for GMO Ident Roundup Ready Soy Kit and $1.5 \%$, w/v; TAE system for in-house method) set at $100 \mathrm{~V}$ for 25-30 min. After completion of electrophoresis, the gel is analysed in the video documentation system. The specific bands obtained have a size of $118 \mathrm{bp}$ for the lectin gene, respectively 128 bp for the P35S-CTP4 genetic construct in the case of the method using a dedicated kit and 172 bp for the GTS 40-3-2 line-specific sequence for the in-house method (Fig. 1).

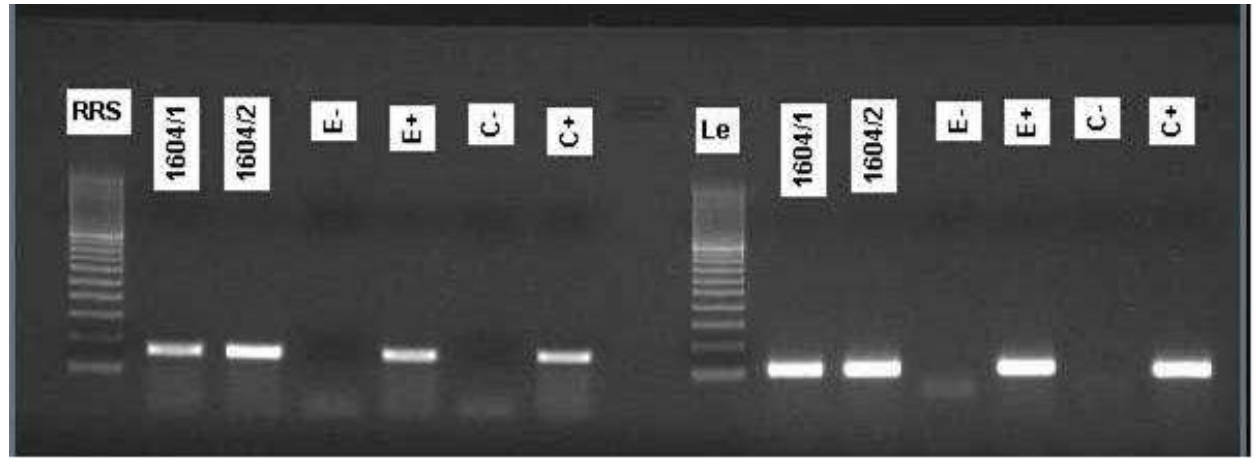

Figure 1. Identification of the specific-DNA to line 40-3-2 and the specific-sequence to the soybean plant Glycine max L. (lectin) by conventional PCR technique. RRS=40-3-2 (Roundup Ready Soy); Le= lectin; $1604 / 1=$ soya beans $/ 1 ; 1604 / 2=$ soya beans; E-= control negative extraction; E+= control positive extraction; $\mathrm{C}-=$ Control negative target $\mathrm{DNA} ; \mathrm{C}+=$ control positive target DNA.

\section{PCR technique for GTS 40-3-2 line- specific DNA quantification}

Quantitative nucleic acid-based methods used in this study were in accord with the standardised methods of analysis for the detection of genetically modified organisms and derived products [ISO, 2005 [20]; ISO, 2005 [22]).

Method was carried out with the GMO Quant (HR) Roundup Ready Soy kit (Eurofins GeneScan, Germany) as per the manufacturer's recommendations with an Applied Biosystems 7900 HT Fast Real-Time PCR System (Invitrogen, SUA) (Fig. 2), at which the following operating parameters have been set: decontamination (UNG) $50^{\circ} \mathrm{C}-2 \mathrm{~min}$; activation of DNA polymerase $95^{\circ} \mathrm{C}-10 \mathrm{~min}$; amplification $95^{\circ} \mathrm{C}-15 \mathrm{sec}, 60^{\circ} \mathrm{C}-1 \mathrm{~min}$, and number of cycles 45 . The kit uses ready-to-use reagents Master Mix (HR) GSEP-07.42 RRS-HT-P/C and Master Mix (HR) Soy lectin 1. The concentration of DNA solutions was adjusted at $\sim 40 \mathrm{ng} / \mu \mathrm{l}$ ( $200 \mathrm{ng}$ DNA / reaction) and at a final volume / reaction of $25 \mu \mathrm{l}$.

$20 \mu \mathrm{l}$ Master Mix + $5 \mu \mathrm{l} \mathrm{DNA} \mathrm{(200} \mathrm{ng)} \mathrm{/} \mathrm{H2O} \mathrm{were}$ pipetted on ice / cooling block avoiding the generation of air bubbles following pipetting, centrifuged in the cold $5 \mathrm{sec}$ at $3000 \mathrm{rpm}$ and placed on the thermocycler.

\section{Results and Discussions}

This study covered the surveillance and monitoring of 40-3-2 events performed by the National Reference Laboratory for Genetically Modified Organisms, hosted by the Molecular Biology Service of the Institute of Diagnosis and Animal Health, between 2013 and 2017 (Table 8).

In 2013, 40-3-2 events were recorded in 32 of 131 soya matrix samples $(24.42 \%)$, of which the soya beans samples were 4 below the $0.9 \%$ threshold and 3 above $0.9 \%$ threshold, the feed with soy samples were 1 below the $0.9 \%$ threshold and 4 above $0.9 \%$ threshold, and the food with soya samples were 10 below the $0.9 \%$ threshold and 10 above $0.9 \%$ threshold. 

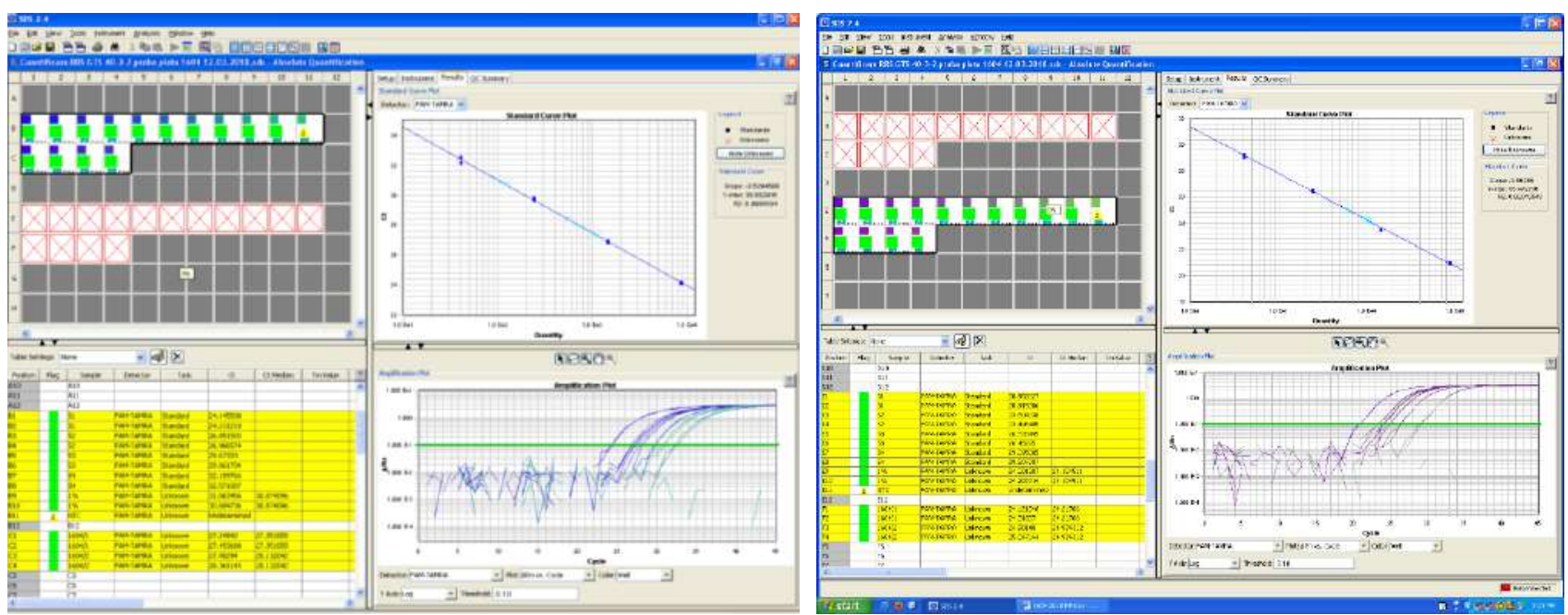

Figure 2. Quantification of DNA specific to line 40-3-2 in both systems (GMO and Species-Ref.) with the GMO Quant (HR) Roundup Ready Soy kit (Eurofins GeneScan, Germany) in Applied Biosystems 7900 HT Fast Real-Time PCR System (Invitrogen, SUA).

Table 8. Determination of the 40-3-2 events in feed and food with soy between 2013 and 2019, in Romania

\begin{tabular}{|c|c|c|c|c|c|c|c|c|}
\hline \multirow{2}{*}{ MATRIX } & Year & $\mathbf{2 0 1 3}$ & $\mathbf{2 0 1 4}$ & $\mathbf{2 0 1 5}$ & $\mathbf{2 0 1 6}$ & $\mathbf{2 0 1 7}$ & $\mathbf{2 0 1 8}$ & $\mathbf{2 0 1 9}$ \\
\hline \multirow{2}{*}{ Event value } & $<0.9 \%$ & 4 & 6 & 4 & 2 & - & - & 1 \\
\hline \multirow{2}{*}{ Feed with soy } & $>0.9 \%$ & 3 & 8 & 13 & 2 & 6 & 2 & 1 \\
\cline { 2 - 10 } & $<0.9 \%$ & 1 & - & - & - & - & - & - \\
\hline \multirow{2}{*}{ Food with soya } & $>0.9 \%$ & 4 & 2 & 2 & 9 & - & 2 & - \\
\cline { 2 - 10 } & $>0.9 \%$ & 10 & 9 & 5 & 3 & - & 4 & - \\
\hline \multicolumn{2}{|c}{ Total } & 10 & - & - & - & - & - & - \\
\hline
\end{tabular}

The tests performed in 2014 revealed 25 events in 142 soya matrix samples $(17.61 \%)$, of which the soya beans samples were 6 below the $0.9 \%$ threshold and 8 above $0.9 \%$ threshold, the feed with soy samples were 2 above $0.9 \%$ threshold, and the food with soya samples were 9 below the $0.9 \%$ threshold.

In 2015, 24 events were recorded in 117 tests, of which the soya beans samples were 4 below the $0.9 \%$ threshold and 13 above $0.9 \%$ threshold, the feed with soy samples were 2 above $0.9 \%$ threshold, and the food with soya samples were 5 below the $0.9 \%$ threshold.

In 2016, 16 events were recorded in 115 tests, of which the soya beans samples were 2 below the $0.9 \%$ threshold and 2 above $0.9 \%$ threshold, the feed with soy samples were 9 above $0.9 \%$ threshold, and the food with soya samples were 3 below the $0.9 \%$ threshold.

In 2017 were tested 97 samples and were recorded only 6 events above $0.9 \%$ threshold in soya beans samples.

In 2018 were recorded 8 events in 53 tests, of which the soya beans samples were 2 above $0.9 \%$ threshold, the feed with soy samples were 2 above $0.9 \%$ threshold, and the food with soya samples were 4 below the $0.9 \%$ threshold.

In 2019 were performed 32 tests and only 2 events were recorded in soya bean samples, one below the $0.9 \%$ threshold and one above $0.9 \%$ threshold.
The surveillance of feed and food in various European and non-European markets proved the circulation of GMO in the last decades (JAMES, 2011; MANDACI \& al, 2014 [23]; SAFAEI \& al, 2020). Some non-European studies, reported over $95 \%$ of soy analysed samples positive at the detection of $35 \mathrm{~S}$ promoter and NOS terminator sequences (SAFAEI \& al, 2020), while other reported that all of the tested food samples contained less than $0.1 \%$ of 5-enol-pyruvyl shikimat-3-phosphate synthase (EPSPS) gene (MANDACI \& al, 2014 [23]).

\section{Conclusions}

The genetically modified organisms' detection in soy feed and food detection is a complex methodology that start with the isolation, purification and quality control of isolated DNA and continue with qualitative PCR methods of the taxon detection (identification of the sequence specific to the Glycine max L.) and the genetic construct detection (identification of the sequence representing the junction region between the CaMV $35 \mathrm{~S}$ promoter and the CTP4), and is finalised with a real-time-PCR technique for GTS 40-3-2 line-specific DNA quantification.

The retrospective analyses revealed 32/131 GM events in 2013, 25/142 GM events in 2014, 24/117 GM events in 2015, 16/115 GM events in 2016, 6/97 GM events 
in $2017,8 / 53 \mathrm{GM}$ events in 2018, and 2/32 GM events in 2019.

\section{References}

1. WORLD HEALTH ORGANIZATION. Frequently asked questions on genetically modified foods. Available at: https://www.who.int/foodsafety/areas_work/foodtechnology/faq-genetically-modified-food/en/ Accessed: 07/18/2020 (2014).

2. C. ZHANG, R. WOHLHUETER, H. ZHANG. Genetically modified foods: A critical review of their promise and problems. Food Science and Human Wellness, 5(3), 116-123 (2016).

3. M. DADGARNEJAD, K. KOUSER, M. MOSLEMI. Genetically Modified Foods: Promises, Challenges and Safety Assessments. Applied Food Biotechnology, 4(4), 193-202 (2017).

4. EUROPEAN UNION. Directive 2001/18/EC on the deliberate release of GMOs into the environment. URL https://eur-lex.europa.eu/legal-content/EN/TXT/?uri= CELEX:32001L0018 Accessed 22.02.22 (2001).

5. EUROPEAN UNION. Regulation (EC) 1829/2003 on genetically modified food and feed. URL https://eur-lex. europa.eu/legal-content/EN/ALL/?uri=CELEX:32003 R1829 Accessed 22.02.22 (2003).

6. EUROPEAN UNION. Regulation (EC) 1830/2003 concerning the traceabilityand labelling of genetically modified organisms and the traceability of food and feed products produced from genetically modified organisms. URL https://eur-lex.europa.eu/legal-content/EN/TXT/?uri= LEGISSUM:121170 Accessed 22.02.22 (2003).

7. EUROPEAN UNION. Directive 2009/41/EC on contained use of genetically modified micro-organisms. Regulation (EC) 1946/2003 on transboundary movements of GMOs. URL https://eur-lex.europa.eu/legal-content/EN/TXT/?uri= CELEX:32009L0041 Accessed 22.02.22 (2009).

8. EUROPEAN UNION. Commission Regulation (EU) No $619 / 2011$ of 24 June 2011 laying down the methods of sampling and analysis for the official control of feed as regards presence of genetically modified material for which an authorisation procedure is pending or the authorisation of which has expired. URL https://eurlex.europa.eu/LexUriServ/LexUriServ.do?uri=OJ:L:2011: 166:0009:0015:EN:PDF Accessed 22.02.22 (2011).

9. EUROPEAN UNION. Directive (EU) 2015/412 amending Directive 2001/18/EC as regards the possibility for the Member States to restrict or prohibit the cultivation of GMOs in their territory. URL https://eur-lex.europa.eu/ legal-content/EN/TXT/?uri=CELEX:32015L0412 Accessed 22.02.22 (2015).

10. M. FRIEDMAN, D.L. BRANDON. Nutritional and health benefits of soy proteins. Journal of Agricultural and Food Chemistry, 49(3), 1069-1086 (2001).

11. K.L. KORTH. Genes and traits of interest for transgenic plants. In C.N. Stewart (Ed.), Plant biotechnology and genetics: principles, techniques and applications (pp. 193-215). New York: John Wiley and Sons. http://dx.doi.org/10.1002/9780470282014.ch8 (2008).
12. C. JAMES. Global status of commercialized biotech/GM Crops (ISAAA Brief, Vol. 43). Ithaca: ISAAA (2011).

13. CROPLIFE INTERNATIONAL. Biotradestatus of GTS 40-3-2. Biotradestatus (2017).

14. S.R. PADGETTE, K.H. KOLACZ, X. DELANNAY, D.B. RE, B.J. LAVALLEE, C.N. TINIUS, W.K. RHODES, Y.I. OTERO, G.F. BARRY, D.A. EICHHOLTZ, V.M. PESCHKE, D.L. NIDA, N.B. TAYLOR, G.M. KISHORE. Development, identification, and characterization of a glyphosatetolerant soybean line. Crop Science, 35, 14511461 (1995).

15. L.T. LAU, R.A. COLLINS, S.H. YIU, J. XING, A.C.H. YU. Detection and characterization of recombinant DNA in the Roundup Ready soybean insert. Food Control, 15, 471-478 (2004).

16. Z. SIERADZKI, M. MAZUR, K. KWIATEK. Validation of procedures based on PCR reactions for detection and identification of genetically modified maize and soybean. Bulletin of the Veterinary Institute in Pulawy, 52, 611-614 (2008).

17. EN/TS 21568:2006 - Foodstuffs. Methods of analysis for the detection of genetically modified organisms and derived products - Sampling strategies; European Committee for Standardization, Brussels, Belgium (2006).

18. ISO 24276:2006 - Foodstuff. Methods of analysis for the detection of genetically modified organisms and derived products - General requirements and definitions (2006).

19. ISO 21571:2005 - Foodstuff. Methods of analysis for the detection of genetically modified organisms and derived products. Nucleic acid extraction; International Organization for Standardization, Geneva (2005).

20. ISO/TS 21098:2005 - Foodstuff. Nucleic acid based methods of analysis of genetically modified organisms and derived products - Information to be supplied and procedure for the addition of methods to ISO 21569, ISO 21570 or ISO 21571; International Organization for Standardization, Geneva, Switzerland (2005).

21. ISO 21569:2005/A1:2013 - Foodstuff. Methods of analysis for the detection of genetically modified organisms and derived products. Qualitative nucleic acid-based methods; International Organization for Standardization, Geneva, Switzerland (2013).

22. ISO 21570:2005/A1:2013 - Foodstuff. Methods of analysis for the detection of genetically modified organisms and derived products. Quantitative nucleic acid-based methods; International Organization for Standardization, Geneva, Switzerland; Switzerland (2013).

23. M. MANDACI, Ö. ÇAKIR, N. TURGUT-KARA, S. MERIÇ, Ş. ARI. Detection of genetically modified organisms in soy products sold in Turkish market. Food Science and Technology, Campinas, 34(4), 717-722 (2014).

24. P. SAFAEI, S. REZAIE, M. ALIMOHAMMADI, S.A.K. AFSHARI, M. MEHDIZADEH, E.M. AGHAEE, Qualitative PCR-based detection of genetically modified soy and maize products in Iran. International Journal of Food Properties, 23:1, 459-469 (2020). 